They have also to put up with periodic bumps as the shuttle is manoeuvred, whereas most space-manufacturing processes, such as growing crystals, call for long periods in a stable environment. That so many companies have nevertheless been prepared to experiment may testify less to their faith in the future of space manufacturing than to the alluring incentives - ranging from free shuttle rides to access to NASA laboratories - that they are being offered.

If NASA has its way, these incentives will grow. A report on space commercialization being mulled over in the White House says that the hoped-for private sector investment in space will not materialize without a massive subsidy in the form of tax credits and risk-sharing agreements. Both NASA and the aerospace industry, however, have a strong vested interest in making the future of space manufacturing look as rosy as possible. Whether there are any real grounds to expect a fair return from a massive public investment is another question.

\section{Weapons in space}

\section{The Soviet and US Governments should return}

\section{to private diplomacy over space weapons.}

WHEN the future of the world may seem to hang on the conversation at a White House barbecue between Mr George Shultz, the US Secretary of State, and Mr Anatoli Dobrynin, the Soviet ambassador to Washington, the time has surely come when ordinary mortals may wonder whether it is not high time that governments conducted their affairs professionally. Hopefully, people have been surmising that the two men were trying to make sense of the latest misunderstanding between the Soviet Union and the United States on arms control. The Soviet Government had issued an invitation to a conference in Vienna in September to negotiate a ban on weapons in space, the United States had complicated its swift acceptance with the statement that it would wish to talk about nuclear weapons as well, the Soviet Union had accused its opposite number of not being "serious" and the possibility that talks might take place was once more up in the air. Whether Shultz and Dobrynin were trying to sort out the muddle or merely planning a fishing trip, time will no doubt tell.

The charge that both governments are behaving unprofessionally is true in the particular sense that they have fallen back on the use of public statements to the international press for doing what ambassadors and other diplomats are employed for. For the past several years, negotiation by press release has been a constant source of trouble. The Geneva talks on nuclear weapons of intermediate range, which began with both sides taking trappist vows, were quickly undermined by the publication of "negotiating positions" which, once public, ceased to be negotiable. That illustrates the most persuasive reason why diplomatic negotiations should, to begin with, be private. Another is that negotiation by public statement entails attempts to capture public support which, if successful, anger the other side. This is nicely illustrated by last weekend's fracas.

The substance of the argument between the Soviet Union and the United States on space weapons is likely to be hopelessly obscured by these events. Two kinds of weapons are involved devices for destroying predictable Earth satellites (now almost realities) and more futuristic star wars weapons, meant for destroying warheads. The case for banning both kinds of systems is straightforward - their deployment by one side would give the other the sense that the strategic balances had become disadvantageously inequitable. But could such an agreement be verified? That is what the US Administration has been asking, properly enough. The simple answer is that, within reasonable limits, it is. The simplest way of arranging this is to require that each side should tell the other the purpose of all rockets fired in such a way as to carry objects into orbits about the Earth or above an altitude of, say, $100 \mathrm{~km}$. That sometimes they would find themselves acknowledging that many Earth satellites have a military function would be no surprise, and an uncovenanted benefit of agreement. Why not try that?

\section{Public going public}

The British Government should revise its policy for selling off public enterprises.

THE British Government, wedded since its election five years ago to the disposal of the publicly-owned commercial corporations acquired by its predecessors, should be given pause by the latest debacle in its flirtation with the London stock markets. Last week, the sale of shares in a company called Enterprise Oil, cobbled together from the interests which the nationalized gas industry had over the years acquired in the North Sea, turned out to be a flop. Three-quarters of the shares were left with the merchant banks which had guaranteed the government the proceeds of the sale (in return for a fee). The government was further embarrassed when it came to light, late in the proceedings, that the multinational company Rio Tinto-Zinc had successfully bid for half the shares on offer. The government has promptly ruled that purchase invalid, incurring the wrath of the City of London for seeming to change the rules half-way through the sales (which allegation remains to be tested).

The following advice (which is free of charge) is offered to help the British Government to avoid similar troubles in the months ahead, when it is committed to selling off part of the nationalized automobile manufacturer (Jaguar cars), a telephone system (British Telecom) and possibly an airline (British Airways).

The motive for the sale of these public assets is twofold. The British Government holds that enterprises which could be owned privately should not remain in public hands, but also needs the cash that the sale of these assets will bring to offset its budget deficit. Thereby it has created a dilemma for itself: the public interest requires that public enterprises should be shorn as far as possible of their monopoly rights before being sold off, but the result is that they raise less cash when offered for sale. The problem is especially acute for the intended sales of the airline and the telephone company, where the government is directly in control of the monopoly rights the two enterprises will continue to enjoy. The other difficulty that has now come to light is more surprising - the government seems incapable of estimating accurately the price at which shares in public enterprises should be sold. Sometimes it underestimates what they will fetch (as with the sale of Amersham International two years ago) and is accused by its opponents of squandering public wealth. Sometimes it overestimates (as with last week's sale of Enterprise Oil) and is laughed at. The root cause of this practical problem is the ambition to sell in one operation either the whole of a publicly owned enterprise (Enterprise Oil) or roughly half of it (British Telecom).

The solution of both problems, the conflict of interest and the pricing difficulty, should however be clear. Assessing the price that shares in a public enterprise will command on the private stock markets is necessarily difficult because, while the government remains the sole owner, stockbrokers cannot "make a market". The way round that obstacle is to let shares dribble onto the market, not to unload them all at once. That, as it happens, is how the British Government is used to selling the financial securities by which it funds its own borrowing. Following such a course in the sale of public enterprises would however sharpen the conflict of interest, for then the government would be conscious that every small regulatory decision about the telephone network or the nationalized airline would affect its cash flow.

The solution is straightforward: transfer the shares in public enterprises due for sale to the equivalent of a trustee of the public interest, whose only function would be to sell shares to all who are prepared to pay the going market price for as long as the supply lasts. The only possible objection to such a policy, that minority shareholds in a company are unduly at a disadvantage, could be countered by requiring that the public trustee should scale down the voting of the shares still on his books so as to match the proportion in private hands. It is mystifying that a government that claims to believe in the market should unimaginatively be trapped by other people's rules. 